\title{
Dose dependent rhizospheric Ni toxicity evaluation: Membrane stability and antioxidant potential of Vigna species
}

Seema Mahmood ${ }^{1}$, Shabnam Ishtiaq ${ }^{1}$, Ghulam Yasin $^{1}$, and Ahsan Irshad ${ }^{2 *}$

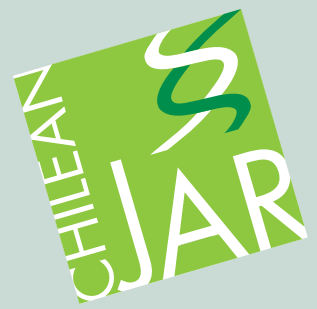

\section{ABSTRACT}

Different concentrations of $\mathrm{Ni}$ are found in agricultural soil released from various environmental sources. The responses of plants grown in such soil-substratum vary accordingly depending upon the concentration of metal present and plant species. To assess the toxic effects of $\mathrm{Ni}$ and extent of plant defensive strategies, increasing $\mathrm{Ni}$ doses $(50,100$, and $150 \mathrm{mg} \mathrm{kg}^{-1}$ ) were used in sandy-loam soil-substratum at $\mathrm{pH} 7.9$ to evaluate the performance of Vigna species (V. cylindrica [L.] Skeels, V. mungo [L.] Hepper, and V. radiata [L.] R. Wilczek). The experiment was conducted in a complete randomized design. Nickel stress was induced by adding various concentrations of $\mathrm{Ni}$ chloride in soil substratum. Malondialdehyde (MDA) and antioxidant levels were determined in roots and leaves. Escalating levels of $\mathrm{Ni}$ in soil resulted in an affirmative relationship between MDA with that of antioxidants. A dose-dependent increase in the activity of Superoxide Dismutases (SOD), Catalase (CAT), and peroxidases (POD) suggested the existence of a sequence response of these enzymes to scavenge oxidative stress in the roots. However, inadequate production of SOD and CAT appeared to be compensated by the enhanced activity of POD, which acted as potent quencher to reactive oxygen species (ROS) in leaves. At the most elevated Ni dose, SOD, CAT and POD activities were insufficient to counteract ROS generated that led to membrane damage manifested by elevated MDA levels. Nevertheless, SOD and CAT alleviated Ni toxicity in roots while SOD, CAT and POD acted in a concurrent manner to protect leaves from oxidative damage in V. cylindrica. The study clearly indicated a $\mathrm{Ni}$ dependent antioxidant enzymes defense system in V.cylindrica.

Key words: Antioxidant defense, catalasa, malondialdehyde (MDA), peroxidases, ROS.

${ }^{1}$ Bahauddin Zakariya University, Institute of Pure and Applied Biology, Multan, Pakistan P.C. 60800.

${ }^{2}$ Institute of Crop Sciences, Chinese Academy of Agricultural Sciences, Beijing 100081, China.

"Corresponding author (ahsanaari@gmail.com).

Received: 21 January 2016.

Accepted: 1 June 2016.

doi:10.4067/S0718-58392016000300017

\section{INTRODUCTION}

Nickel (Ni) is a heavy metal naturally occurring in concentrations of $100 \mathrm{mg} \mathrm{kg}^{-1}$ and $0.005 \mathrm{mg} \mathrm{L}^{-1}$, in soil and water respectively (Chen et al., 2009; Bermudez et al., 2012). Soils derived from serpentine rocks are rich in Ni. Moreover, in the recent years, rapid industrialization and high anthropogenic pressures in the developing countries have caused 20-30 times increase of Ni concentration in the environment (Yusuf et al., 2012). The contamination of $\mathrm{Ni}$ in agricultural soils also results from industrial and municipal wastes, vehicular emissions, Ni fertilizers, electroplating, food industry and electric batteries (Tian et al., 2012; Sreekanth et al., 2013; Kaveriammal and Subramani, 2015). Consequently, the soil act as an ultimate sink of Ni then taken up by plants and enters the food webs (Ashok et al., 2010; Hussain et al., 2013; Mahar et al., 2015).

One of the important consequences of $\mathrm{Ni}$ induced phytotoxicity is the enhanced production of reactive oxygen species (ROS) which generates oxidative stress in plants (Kumar et al., 2012). The most damaging oxidative effect is lipid peroxidation of biological membranes, which results in the concomitant production of malondialdehyde (MDA). Thus, MDA levels have widely been utilized to estimate membrane stability potential in plants under metal stress (Dubey and Pandey, 2011).

The excessive ROS is scavenged by the production of both enzymatic and non enzymatic antioxidants to maintain normal metabolism and such strategies are universal features of plant defense to minimize oxidative damage (Ismail and Theodor, 2013). Oxidative damage could result when the balance between the detoxification of the ROS products and the antioxidative system is altered (Yusuf et al., 2011). The antioxidative activity may be of fundamental significance for the plants in their response against heavy metal stress including Ni (Fargasova, 2012). However, excess Ni has been found to reduce the activity of many cellular antioxidant enzymes and plant's capability to scavenge ROS, leading to ROS accumulation and finally oxidative stress in plants (Gill and Tuteja, 2010). Nevertheless, the plants have an innate ability to balance between generation and degradation of ROS (Gajewska et al., 2013). However, the activity of antioxidant enzymes may vary with the duration and type of stress treatment and within plant species (Gajewska and Sklodowska, 2007).

Superoxide dismutases (SODs) catalyze the dismutation of the superoxide radical $\left(\mathrm{O}_{2}^{-}\right)$into hydrogen peroxide $\left(\mathrm{H}_{2} \mathrm{O}_{2}\right)$ and elemental oxygen $\left(\mathrm{O}_{2}\right)$ Among antioxidant enzymes, superoxide dismutase (SOD) is the major $\mathrm{O}_{2}^{-}$scavenger and its enzymatic action results in $\mathrm{H}_{2} \mathrm{O}_{2}$ and $\mathrm{O}_{2}$ formation. Catalase (CAT) and 
several classes of peroxidases (POD) then scavenge the $\mathrm{H}_{2} \mathrm{O}_{2}$ produced. CAT dismutates $\mathrm{H}_{2} \mathrm{O}_{2}$ into $\mathrm{H}_{2} \mathrm{O}$ and $\mathrm{O}_{2}$ (Mishra et al., 2010) and finally POD decomposes $\mathrm{H}_{2} \mathrm{O}_{2}$ by oxidation of co-substrates such as phenolic compounds and/or antioxidants (Awasthi and Sinha, 2013). Thus, the activities of SOD, CAT, and POD have been well reported in plants species in response to heavy metal stress (NadgorskaSocha et al., 2013; Ismail and Theodor, 2013).

Vigna species (Vigna cylindrica [L.] Skeels, Vigna mungo [L.] Hepper, and Vigna radiata [L.] R. Wilczek) are regarded as pulses/beans. They are important components of human diet all over the world because they contain high amount of easily digestible proteins. In addition, they are the best and least expensive sources of vegetable protein therefore serve as a substitute of meat protein for a significant proportion of population of the poor countries (Suneja et al., 2011; Nair et al., 2013). In Pakistan they are cultivated on 5\% of the total cropped area (20 430000 ha; PARC, 2012).

There exists little information on the formation of oxygen free radicals, membrane stability and antioxidative enzymes in response to $\mathrm{Ni}$ toxicity in Vigna species. Therefore, we investigated oxidative damage via lipid peroxidation and sequence of defensive responses represented by antioxidant enzymes (SOD, CAT, and POD) in tissues (roots and leaves) of Vigna species and their interspecific antioxidant potential in response to increasing doses of $\mathrm{Ni}$ for elaboration of mechanism for oxidative defense.

\section{MATERIALS AND METHODS}

Air-dried sandy loam soil substratum, pH 7.9, sieved through a $2 \mathrm{~mm}$ sieve was thoroughly mixed with nickel(II) chloride hexahydrate $\left(\mathrm{NiCl}_{2} \cdot 6 \mathrm{H}_{2} \mathrm{O}\right)$ (Merck, Darmstadt, Germany) to generate 50,100 and $150 \mathrm{mg} \mathrm{Ni} \mathrm{kg}^{-1}$ oil, while control plants were grown in soil without Ni. Since Ni salt was hexahydrated therefore actual concentration factor of $\mathrm{Ni}$ (4.05 g) was used to maintain $\mathrm{Ni}$ levels used in the study. The selected concentrations were used on the basis of Ni content reported in agriculture soils of Pakistan (sandy loam with $\mathrm{pH}$ 7.9) present in the vicinities of large cities and industries (Ishtiaq and Mahmood, 2011).

Sterilized seeds of V. cylindrica 'cp-386', V. mungo '60367 ' and V. radiata '97003' were obtained from Pulse Crop Division, Ayub Agriculture Research Institute, Faisalabad, Pakistan.

The experiment was arranged in a complete randomized manner. To simulate field conditions, plants were grown in a wire netting house under natural conditions $\left(28 \pm 5^{\circ} \mathrm{C}\right.$, 12:12 h photoperiod, and $38 \% \mathrm{RH})$. Eight (pre-germinated) 6 d-old seedlings were transplanted into each of 36 earthen pots (height $45 \mathrm{~cm}$ and internal diameter $30 \mathrm{~cm}$ ), which were filled with $8.0 \mathrm{~kg}$ soil substratum containing Ni. Seedlings were acclimatized for $1 \mathrm{wk}$ then thinned out to four in each pot. Watering was carried out by gentle spraying using a spray gun to avoid leaching. Fifty days after germination, plants were harvested and leaves and roots were separated carefully for biochemical analyses.
Membrane stability was determined in terms of MDA concentrations in root and leaves by the method of Cakmak and Horst (1991) with minor modifications. Leaf and root samples (each $1.0 \mathrm{~g}$ ) were homogenized in $3 \mathrm{~cm}^{3}$ of $0.1 \%$ $(\mathrm{w} / \mathrm{v})$ trichloroacetic acid (TCA) solution. The homogenate was centrifuged at $20000 \times \mathrm{g}$ for $15 \mathrm{~min}$. Three $\mathrm{cm}^{3}$ of $0.5 \%$ thiobarbituric acid (TBA) prepared in $20 \%$ TCA were added to $0.5 \mathrm{~cm}^{3}$ supernatant. The mixture was heated at $95^{\circ} \mathrm{C}$ in a shaking water bath for $50 \mathrm{~min}$. The reaction was stopped by cooling the tubes in an ice water bath. Then the samples were centrifuged at $10000 \times \mathrm{g}$ for $10 \mathrm{~min}$, and the absorbance of the supernatant read at 532 and $600 \mathrm{~nm}$. The MDA concentration was calculated as the difference in absorbance at 600 and $532 \mathrm{~nm}$ using extinction coefficient of $156 \mathrm{mmol}^{-1} \mathrm{~cm}^{-1}$.

For determination of antioxidants enzymes, fresh leaves and roots $(0.5 \mathrm{~g})$ were ground using a pestle and mortar in $5 \mathrm{~cm}^{3}$ of cooled $50 \mathrm{mM}$ phosphate buffer $(\mathrm{pH}$ 7.8). After filtration through cheesecloth, the homogenate was centrifuged at $15000 \times \mathrm{g}$ for $20 \mathrm{~min}$ at $4{ }^{\circ} \mathrm{C}$ and the supernatant was used in further assay for superoxide dismutase (SOD) activity (Giannopolitis and Ries, 1977), peroxidase and catalase activity (Chance and Maehly, 1955) by recoding absorbance at 560,240 , and $470 \mathrm{~nm}$ respectively.

SOD activity inhibits the photochemical reduction of nitro blue tetrazolium (NBT) at $560 \mathrm{~nm}$. The monitoring of this inhibition is used to assay SOD activity. The reaction mixture was prepared by taking $0.050 \mathrm{~cm}^{3}$ enzyme extract and adding $1 \mathrm{~cm}^{3}$ NBT $(50 \mu \mathrm{M}), 0.5 \mathrm{~cm}^{3}$ methionine (13 $\mathrm{mM}), 1 \mathrm{~cm}^{3}$ riboflavin $(1.3 \mu \mathrm{M}), 0.95 \mathrm{~cm}^{3}(50 \mathrm{mM})$ phosphate buffer and $0.5 \mathrm{~cm}^{3}$ EDTA $(75 \mathrm{mM})$. This reaction was started by keeping reaction solution under $30 \mathrm{~W}$ fluorescent lamp illuminations and turning the fluorescent lamp on. The reaction stopped when the lamp turned off 5 min later. The NBT photo reduction produced blue formazane, which was used to measure the increase in absorbance at $560 \mathrm{~nm}$. The same reaction mixtures without enzyme extract in dark were used as blank. The SOD activity was determined and expressed as SOD I $\mu \mathrm{min}^{-1} \mathrm{mg}^{-1}$ protein (Giannopolitis and Ries, 1977) (1 unit is the amount of SOD which inhibits the rate of increase in absorbance due to NBT-diformazan formation by $50 \%$ ).

Catalase (CAT) activity assayed by the decomposition of $\mathrm{H}_{2} \mathrm{O}_{2}$ and change in absorbance due to $\mathrm{H}_{2} \mathrm{O}_{2}$ was observed every $30 \mathrm{~s}$ for $5 \mathrm{~min}$ at $240 \mathrm{~nm}$ using a UV-visible spectrophotometer (Hitachi 2000, Japan). Reaction mixture for CAT contained $0.9 \mathrm{~cm}^{3} \mathrm{H}_{2} \mathrm{O}_{2}(5.9 \mathrm{mM})$ and $2 \mathrm{~cm}^{3}$ phosphate buffer $(50 \mathrm{mM})$. Reaction was started by adding $0.1 \mathrm{~cm}^{3}$ enzyme extract to the reaction mixture. The CAT activity was expressed as $\mu \mathrm{mol} \mathrm{H}_{2} \mathrm{O}_{2} \mathrm{~min}^{-1} \mathrm{mg}^{-1}$ protein (Chance and Maehly, 1955).

Peroxidase (POD) activity assayed by guaiacol oxidation and defined as 0.01 absorbance change $\mathrm{min}^{-1} \mathrm{mg}^{-1}$ protein. The reaction mixture was prepared by adding $0.4 \mathrm{~cm}^{3}$ guaiacol $(20 \mathrm{mM}), 0.5 \mathrm{~cm}^{3} \mathrm{H}_{2} \mathrm{O}_{2}(40 \mathrm{mM})$ and $2 \mathrm{~cm}^{3}$ phosphate $(50$ $\mathrm{mM}$ ) in $0.1 \mathrm{~cm}^{3}$ enzyme extract. The change in absorbance at $470 \mathrm{~nm}$ of the reaction mixture was observed every $20 \mathrm{~s}$ 
up to $5 \mathrm{~min}$. The POD activity expressed as $\mathrm{mmol} \mathrm{min}^{-1} \mathrm{mg}^{-1}$ protein (Chance and Maehly, 1955).

\section{Statistical analysis}

The statistical analysis was performed on data replicated thrice. Each parameter was subjected to a three-way ANOVA using COSTAT (1998-2004 Cohort Software) in order to determine significant differences among Ni levels, species and their tissues for the biochemical analyses carried out. Significant Differences (LSD) between means for each main factor were calculated by employing a multiple range test following Snedecor and Cochran (1989).

\section{RESULTS}

In this study, the formation of MDA was considered as a measure of lipid peroxidation in leaves (Figure 1a) and roots (Figure 1b) of three Vigna species. It is evident from data that elevation of MDA in both tissues (leaves and roots) of all the species occurred in response to $\mathrm{Ni}$ toxicity in a concentration dependent manner. The MDA contents were greater in roots of the species being the highest $\left(12.5 \mathrm{mmol}^{-1}\right.$ $\mathrm{cm}^{-1}$ ) for $V$. mungo at $150 \mathrm{mg} \mathrm{Ni} \mathrm{kg}^{-1}$ as compared with leaves $\left(9.25 \mathrm{~m} \mathrm{~mol}^{-1} \mathrm{~cm}^{-1}\right)$ followed by $V$. radiata. The extent of

Figure 1. Malondialdehyde (MDA) content in leaves (a) and roots (b) of three Vigna species in response to varying $\mathrm{Ni}$ levels. Results are the mean of three replicates $\pm \mathrm{SE}$.
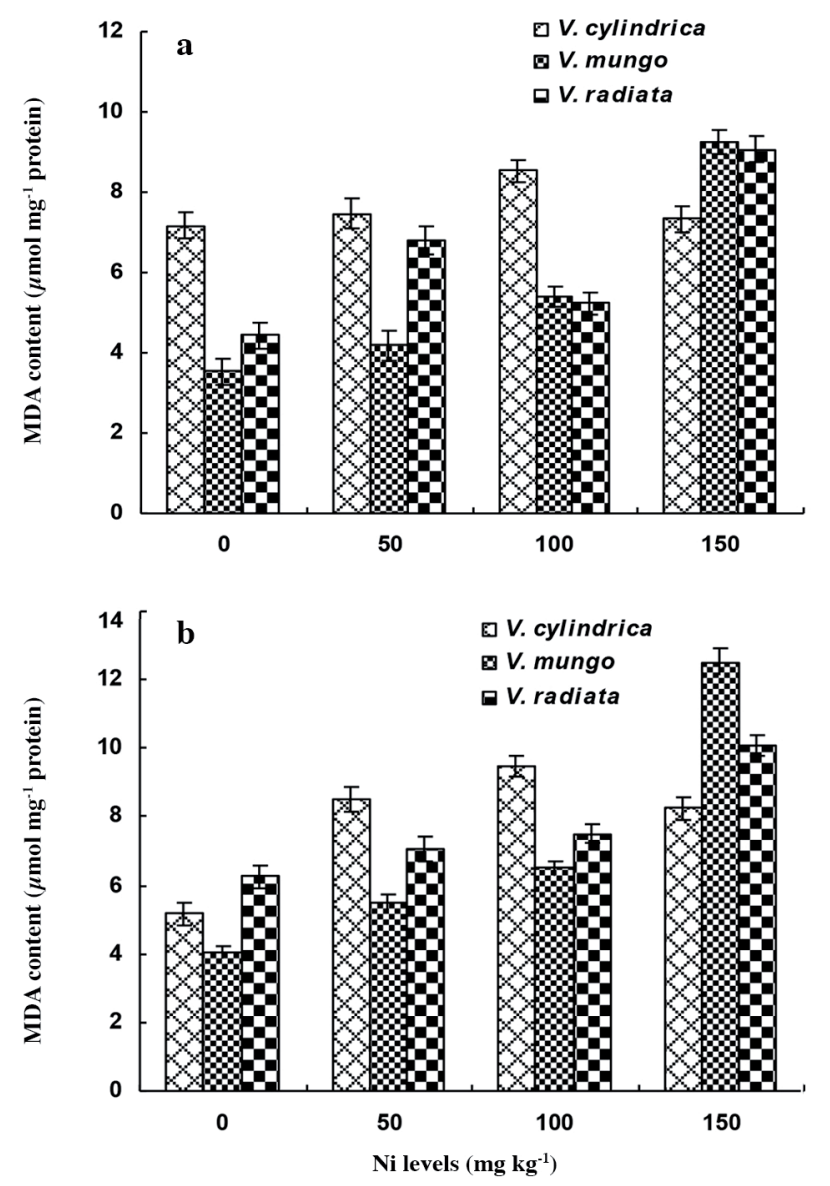

elevation of MDA in V. mungo was $210 \%$ and $162 \%$ in roots and leaves, respectively at $150 \mathrm{mg} \mathrm{Ni} \mathrm{kg}^{-1}$. A steady increase in leaf MDA content was also observed in V. cylindrica at 50 and $100 \mathrm{mg} \mathrm{kg}^{-1}$ and showed $4 \%$ and $19 \%$ rise, respectively. The most significant increase $(83 \%)$ in MDA was noticed in roots of $V$. cylindrica at $100 \mathrm{mg} \mathrm{Ni} \mathrm{kg}{ }^{-1}$ when compared to its respective control. The species had significantly $(P<0.001)$ variable responses to $\mathrm{Ni}$ application and likewise the MDA content in the tissues also varied markedly $(P<0.001)$ as shown in Table 1.

There has been observed a progressive increase in SOD activity in leaves (Figure 2a) and roots (Figure $2 b)$ of the species after exposure to Ni levels. The change in SOD activity in roots was more pronounced in $V$. cylindrica (174.67 $\mu \mathrm{mg}^{-1}$ protein) followed by $V$. radiata (150.33 $\mu \mathrm{mg}^{-1}$ protein) after exposure to higher $\mathrm{Ni}$ concentrations. SOD production in leaves was slightly lower at $50 \mathrm{mg} \mathrm{kg}^{-1}$ for all Vigna species. A consistently lower SOD activity in both tissues of $V$. mungo was observed at the most elevated Ni level. The results (Table 1) also depicted differential production of SOD in the tissues $(P<0.001)$ marked contrast between species $(P<0.001)$.

A consistent increase in CAT was observed in leaves of Ni-treated plants of Vigna species but stronger CAT activity was observed in $V$. cylindrica and $V$. radiata at $150 \mathrm{mg} \mathrm{Ni}$ $\mathrm{kg}^{-1}$ (Figure 2c). However, at $150 \mathrm{mg} \mathrm{kg}^{-1}$ the degree of increase in V. cylindrica was up to $162 \%$ when compared with control. The most elevated Ni level induced $78 \%$ rise in leaf CAT in V. radiata followed by $44 \%$ in $V$. mungo. In roots, more profound change (139\% rise) in the CAT activity was observed in V. radiata in response to the most elevated Ni level (Figure 2d).

Table 1. ANOVA of the activity of superoxide dismutase (SOD), catalase (CAT) and peroxidases (POD) in leaves and roots of three Vigna species in response to varying Ni levels.

\begin{tabular}{llccc}
\hline & MDA & SOD & CAT & POD \\
\hline Plant tissues & & & & \\
Significant range & $* * *$ & $* * *$ & $* * *$ & $* * *$ \\
LSD & 0.135 & 2.149 & 0.675 & 0.01 \\
Leaves & $7.53 \mathrm{a}$ & $138.47 \mathrm{a}$ & $12.33 \mathrm{a}$ & $0.99 \mathrm{a}$ \\
Roots & $6.45 \mathrm{~b}$ & $64.25 \mathrm{~b}$ & $8.24 \mathrm{~b}$ & $0.17 \mathrm{~b}$ \\
\hline Species & \multicolumn{5}{c}{} & \\
Significant range & $* * *$ & $* * *$ & $* * *$ & $* * *$ \\
LSD & 0.110 & 2.631 & 0.826 & 0.01 \\
$V$. cylindrica & $8.50 \mathrm{a}$ & $114.29 \mathrm{a}$ & $9.53 \mathrm{a}$ & $0.71 \mathrm{a}$ \\
$V$. mungo & $7.09 \mathrm{~b}$ & $102.42 \mathrm{~b}$ & $12.75 \mathrm{~b}$ & $0.56 \mathrm{~b}$ \\
V. radiata & $5.37 \mathrm{c}$ & $87.37 \mathrm{c}$ & $8.58 \mathrm{c}$ & $0.46 \mathrm{c}$ \\
\hline Ni levels, mg kg ${ }^{-1}$ & \multicolumn{5}{c}{} & \\
Significant range & $* * *$ & $* * *$ & $* * *$ & $* * *$ \\
LSD & 0.156 & 3.039 & 0.95 & 0.014 \\
Control & $7.42 \mathrm{a}$ & $114.44 \mathrm{a}$ & $12.17 \mathrm{a}$ & $0.69 \mathrm{a}$ \\
50 & $6.93 \mathrm{~b}$ & $113.5 \mathrm{a}$ & $12.02 \mathrm{a}$ & $0.61 \mathrm{~b}$ \\
100 & $6.84 \mathrm{~b}$ & $89 \mathrm{~b}$ & $10.05 \mathrm{~b}$ & $0.56 \mathrm{c}$ \\
150 & $6.76 \mathrm{~b}$ & $88.5 \mathrm{~b}$ & $6.91 \mathrm{c}$ & $0.45 \mathrm{~d}$ \\
\hline
\end{tabular}

***Significant at the 0.001 probability level.

Each value represents mean of three replicates. Means were compared using ANOVA. Data followed by different letters (a-d) in respective columns are significantly different at $P<0.05$.

LSD: Least significant difference. 
Figure 2. The activities of superoxide dismutase (SOD, a) catalase (CAT, c), and peroxidases (POD, e), in leaves and SOD (b), CAT (d), and POD (f) in roots of three Vigna species in response to varying Ni levels. Results are the mean of three replicates \pm SE.
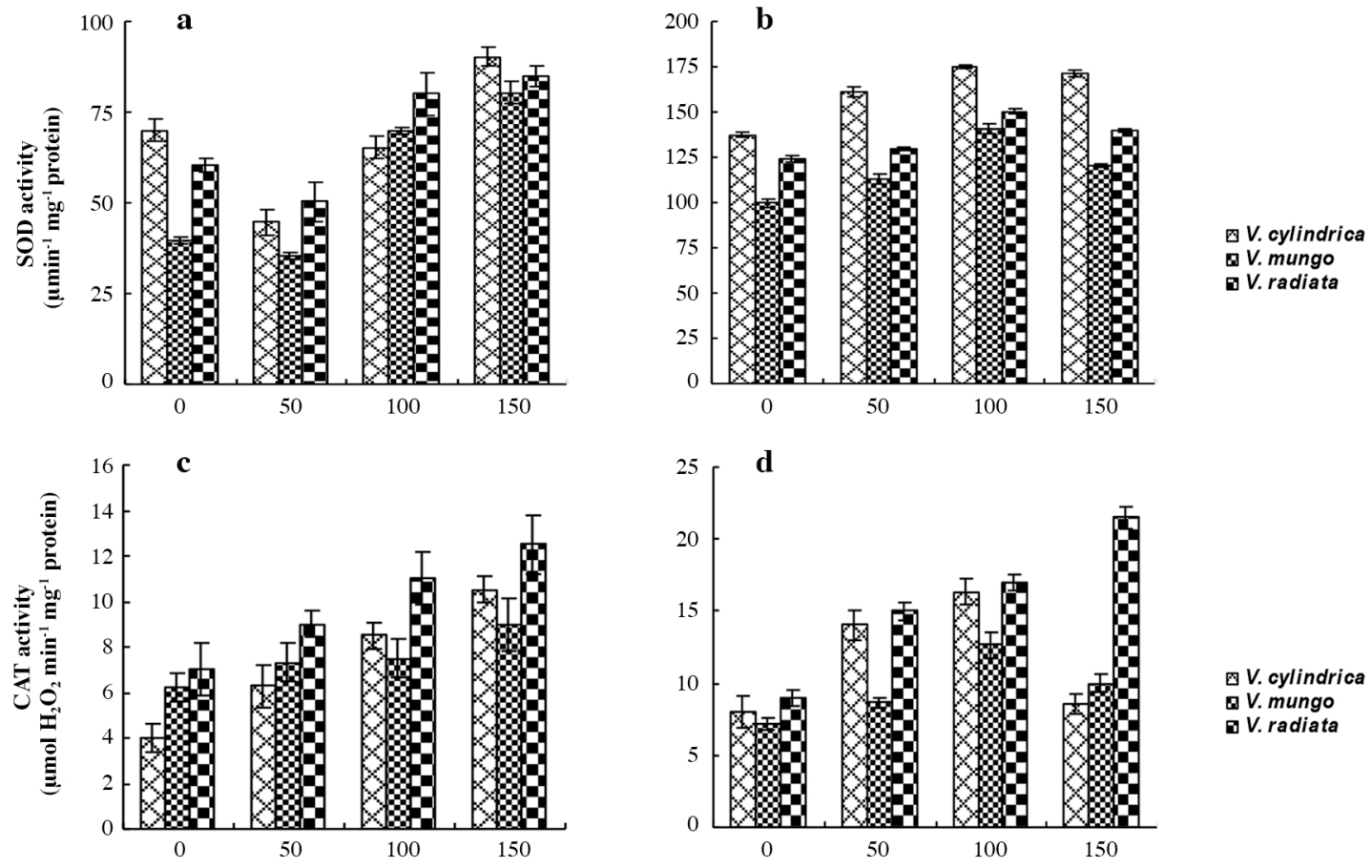

V. cylindrica
Q. mungo

V. radiata
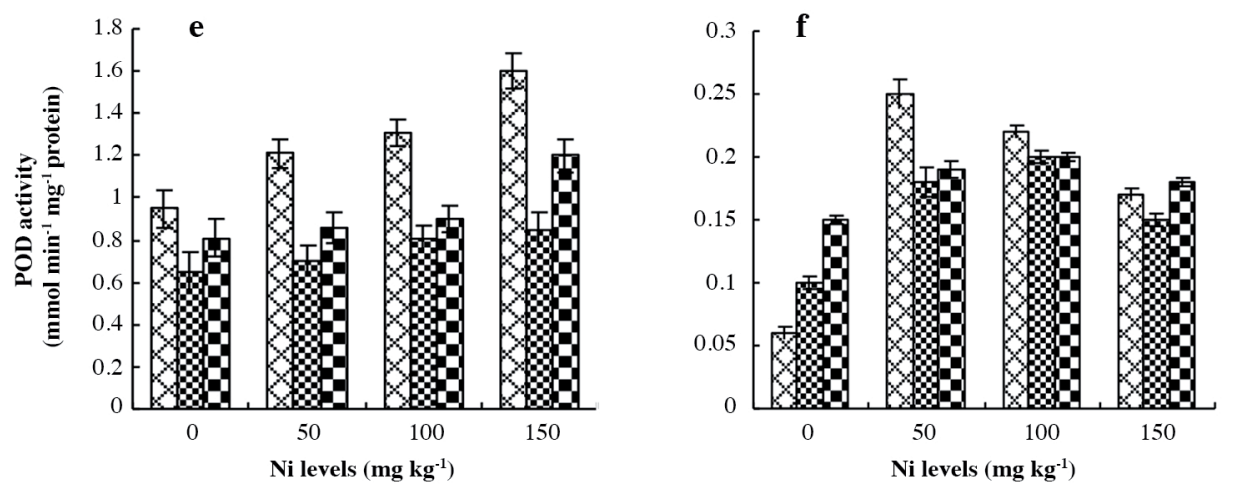

Q V. cylindrica

Q V. mungo

V. V. radiata

Figure 2e depicted that the Vigna species had a supreme approach of POD activity in leaves in response to $\mathrm{Ni}$ applications. At $150 \mathrm{mg} \mathrm{Ni} \mathrm{kg}^{-1}$, POD activity peaked (68\% rise) in leaves of $V$. cylindrica followed by $V$. radiata and $V$. mungo, which showed $48 \%$ and $31 \%$ elevation, respectively than their control plants. A steady increase in POD activity was also noticed in roots of Vigna species with increasing Ni levels (Figure 2f). POD activity changed drastically in the roots of V. cylindrica by $183 \%$ at $150 \mathrm{mg} \mathrm{kg}^{-1} \mathrm{Ni}$. However, no marked increase in POD activity became evident in roots of $V$. radiata. In general, POD activity enhanced greatly $(P<$ 0.001) leaves than roots (Table 1).

\section{DISCUSSION}

Oxidative stress in higher plants induced by heavy metals leads to the generation of superoxide radical $\left(\mathrm{O}^{-2}\right)$, hydrogen peroxide $\left(\mathrm{H}_{2} \mathrm{O}_{2}\right)$, hydroxyl radical $\left(\mathrm{OH}^{-}\right)$, and singlet oxygen $\left(1 \mathrm{O}_{2}\right)$, collectively termed ROS (Kazemi et al., 2010). ROS

can damage all classes of biological molecules such as nucleic acids, proteins, lipids, and amino acids (Hussain et al., 2013) causing irreparable tissue damage and ultimately cell death (Awasthi and Sinha, 2013).

Toxic effects of $\mathrm{Ni}$ are probably exerted through free radical generation, which results in the enhanced production of MDA (a lipid peroxidation product) in Vigna species. The results of this study indicated rapid and continuous lipid peroxidation stimulated by $\mathrm{Ni}$ and assessed as MDA concentration (Table 1). The fast rise of membrane lipid peroxidation could be due to direct contact of roots with the metal (Dubey and Pandey, 2011; Singh et al., 2013). Several other studies demonstrated that $\mathrm{Ni}$ toxicity contributed enhanced generation of ROS, thus peroxidative damage to membrane lipids is highly likely (Das et al., 2008; Gill and Tuteja, 2010). Moreover, Ni-induce depletion of some low molecular weight proteins (GSH), may lead to damage of membrane, thus, may contribute to the induction of oxidative stress in plants (Sreekanth et al., 2013). 
Heavy metals enters many types of cells and under physiological conditions can be reduced by hydrogen peroxide $(\mathrm{HO})$, glutathione $(\mathrm{GSH})$ reductase, ascorbic acid, and GSH to produce reactive intermediates, including thiyl radicals, hydroxyl radicals, etc. Any of these species could attack DNA, proteins, and membrane lipids, thereby disrupting cellular integrity and functions.

The result indicated that more SOD and CAT activities was noticed in roots of $V$. cylindrica followed by $V$. radiata under high Ni doses, while insufficient responses of SOD and CAT to scavenge oxidative stress in leaves of all the Vigna species were balanced by the enhanced activity of POD to protect leaves from oxidative damage (Figure 2). A protective mechanism to minimize oxidative damage generated by ROS initiates which comprises the production of important antioxidant enzymes including SOD, CAT, and POD (Lu et al., 2010; Idrees et al., 2013). Exposure of plants to $\mathrm{Ni}$ at low concentrations $(0.05 \mathrm{mM})$ for short times has been shown to increase the activity of the antioxidant enzymes of the ascorbate-glutathione cycle (Kachout et al., 2009), which protect plant cells against free radicals by removing (or scavenging) of ROS (Ismail and Theodor, 2013).

The minimum activity of SOD in $V$. mungo at $150 \mathrm{mg} \mathrm{kg}^{-1}$ (Table 1) indicated that the least adaptive nature of $V$. mungo. While, SOD activity in roots of $V$. cylindrica and $V$. radiata peaked at higher $\mathrm{Ni}$ concentrations suggesting that this increase in SOD has better protection against oxidant damage. This increase in the concentration of SOD in V.cylindrica and $V$. radiata under high $\mathrm{Ni}$ doses might be due to the induction of genes of SOD by superoxide mediated signal transduction, which causes de novo synthesis of enzyme proteins (Tewari et al., 2008) and thus causing more superoxide generation. The enzyme concentrations were more increased under high $\mathrm{Ni}$ supplements and thus the higher concentration of antioxidant enzymes were involved in the protective mechanisms adapted by plants. This can be correlated to the increased stress tolerance (Awasthi and Sinha, 2013). A rise in SOD concentration in the observe study was found to be more pronounced in roots as compared to leaves (Table 1). Such increase in the activity of these enzymes has also been reported with a direct contact of root with the metal applied for treatments and the extent of increase varied with the metal concentration and the plant species (Duman and Ozturk, 2010; Hussain et al., 2013). Decrease in SOD activity might be due to the competitive uptake of $\mathrm{Ni}$ against the other metals ions being the co-factors used by respective forms of this enzyme (Pandey and Sharma, 2002) as well as to its inactivation by $\mathrm{H}_{2} \mathrm{O}_{2}$ or other ROS (Lu et al., 2010).

Some forms of antioxidant could be rendered inadequate in the species because of the higher Ni doses induced alterations in the activities of alternate enzymes of antioxidant defense (SOD, CAT). The oxidative damage to membrane in $\mathrm{Ni}$ stress $V$. mungo could be due to accumulation of $\mathrm{H}_{2} \mathrm{O}_{2}$ and a consequent of enhanced activity of SOD and inhibition of CAT. The increase in SOD and decrease in CAT activity in response to excess $\mathrm{Ni}$ supply has been widely reported by other workers also (Pandey et al., 2009).
POD is a stress marker enzyme located in the cell wall, vacuole and extracellular spaces utilize $\mathrm{H}_{2} \mathrm{O}_{2}$ to generate phenoxy compounds that polymerize to produce lignin (Gajewska and Sklodowska, 2010) and is involved in strengthening of the cell wall by promoting lignin biosynthesis (Chaoui and El-Ferjani, 2005). Thus, the stronger cell wall itself acts as a physical barrier against toxic metal ions (Fargasova, 2012). The substrate affinity of POD is higher than that of CAT (Mhamdi et al., 2010). Therefore, the results indicated that $V$. cylindrica might efficiently avoid heavy metal by showing its capacity to produce more POD. The POD activity of both the roots and the leaves of $V$. cylindrica, at increasing doses of $\mathrm{Ni}$, suggested that POD can affect $\mathrm{H}_{2} \mathrm{O}_{2}$ detoxification. The reduction in CAT at high $\mathrm{Ni}$ concentration might be due to the condition that during stress condition the tetrameric CAT molecules may degrade into monomeric CAT subunits, which act like POD (Panda and Khan, 2003). Moreover, Gajewska and Sklodowska (2010) described that peroxidase-catalyzed reactions, including lignification and cross-links formation, result in decreased cell wall plasticity and consequently in its restricted elongation. POD itself might be utilized in consuming $\mathrm{H}_{2} \mathrm{O}_{2}$ to generate phenoxy compounds that are polymerized to produce cell wall components such as lignans (Kovacik et al., 2009). Increased POD activity shown in our results is correlated with Ni stress suggesting it to be an intrinsic defense tool and can be related with the release of peroxidase localized in the cell walls (Chen et al., 2000). These results are in consonance with earlier reports which also indicated that lower response of SOD activity compensated by the increased activities of CAT and POD (Maheshwari and Dubey, 2009; Duman and Ozturk, 2010; Ismail and Theodor, 2013).

\section{CONCLUSIONS}

It was concluded from this study that applied $\mathrm{Ni}$ implication (100-150 $\mathrm{mg} \mathrm{kg}^{-1}$ ) induced lipid peroxidation leading to membrane damage as evident from enhanced malondialdehyde concentration. This oxidative damage was more profound in roots than leaves due to direct contact of membrane root with the metal. Under high doses of $\mathrm{Ni}$, superoxide dismutase and catalase appeared to be compensated by the enhanced activity of peroxidases as potent quencher to reactive oxygen species in leaves. Among the species, Vigna mungo was most sensitive and $V$. cylindrica was the most tolerant under high Ni doses.

\section{ACKNOWLEDGEMENT}

Data presented in this manuscript are a part of $\mathrm{PhD}$ research studies of Ms. Shabnam Ishtiaq (Registered PhD student), Institute of Pure and Applied Biology, Botany Division, Bahauddin Zakariya University Multan, Pakistan P.C. 60800. The research grant awarded by Indigenous $\mathrm{PhD}$ fellowship for 5000 scholars, Phase II Higher Education Commission HRD Division, Sector H-9, Islamabad, Pakistan. 


\section{REFERENCES}

Ashok, K., B.S. Bisht, K. Manish, and K. Lalit. 2010. Effects of Ni and $\mathrm{Zn}$ on growth of Vigna mungo, Vigna radiata and Glycine max. International Journal of Pharmacy and Biological Sciences 2:1-7.

Awasthi, K., and P. Sinha. 2013. Nickel stress induced antioxidant defence system in sponge gourd (Luffa cylindrica). Journal of Plant Physiology \& Pathology 1:1.

Bermudez, G.M.A., R. Jasan, R. Pla, and M.L. Pignata. 2012. Heavy metals and trace elements in atmospheric fall-out: Their relationship with topsoil and wheat element composition. Journal of Hazardous Materials 213-214:447-456.

Cakmak, I., and W.J. Horst. 1991. Effect of aluminum on lipid peroxidation, superoxide dismutase, catalase and peroxidase activities in root tips of soybean (Glycine max). Physiologia Plantarum 83:463-468.

Chance, B., and A.C. Maehly. 1955. Assay of catalases and peroxidases. Methods in Enzymology 2:764-775.

Chaoui, A., and E. El-Ferjani. 2005. Effect of cadmium and copper on antioxidant capacities, lignification and auxin degradation in leaves of pea (Pisum sativum L.) seedlings. Comptes Rendus Biologies 328:23-31.

Chen, C., D. Huang, and J. Liu. 2009. Functions and toxicity of nickel in plants: Recent advances and future prospects. Clean Soil Air Water 37:304-313.

Chen, L.M., C.C. Lin, and C.H. Kao. 2000. Copper toxicity in rice seedlings: changes in antioxidative enzyme activities, $\mathrm{H}_{2} \mathrm{O}_{2}$ level, and cell wall peroxidase activity in roots. Botanical Bulletin of Academia Sinica 41:99-103.

Das, K.K., S.N. Das, and S.A. Dhundasi. 2008. Nickel, its adverse health effects and oxidative stress. Indian Journal of Medical Research 128:412-425.

Dubey, D., and A. Pandey. 2011. Effect of nickel (Ni) on chlorophyll, lipid peroxidation and antioxidant enzymes activities in black gram (Vigna mungo) leaves. International Journal of Science and Nature 2:395-401.

Duman, F., and F. Ozturk. 2010. Nickel accumulation and its effect on biomass, protein content and antioxidative enzymes in roots and leaves of watercress (Nasturtium officinale R. Br.) Journal of Environmental Sciences 22:526-532.

Fargasova, A. 2012. Plants as models for chromium and nickel risk assessment. Ecotoxicology 21:1476-1483.

Gajewska, E., and M. Sklodowska. 2007. Effect of nickel on ROS content and antioxidative enzyme activities in wheat leaves. BioMetals 20:27-36.

Gajewska, E., and M. Sklodowska. 2010. Differential effect of equal copper, cadmium and nickel concentration on biochemical reactions in wheat seedlings. Ecotoxicology and Environmental Safety 73:996-1003.

Gajewska, E., E. Niewiadomsk, K. Tokarz, M. Slab, and M. Sklodowsk. 2013. Nickel-induced changes in carbon metabolism in wheat shoots. Journal of Plant Physiology 170:369-377.

Giannopolitis, C.N., and S.K. Ries. 1977. Superoxide dismutase I. Occurrence in higher plants. Journal of Plant Physiology 59:309-314

Gill, S.S., and N. Tuteja. 2010. Reactive oxygen species and antioxidant machinery in abiotic stress tolerance in crop plants. Plant Physiology and Biochemistry 48:909-930.

Hussain, M.B., S. Ali, A.H.S. Azam, M.A. Farooq, B. Ali, S.A. Bharwana, et al. 2013. Morphological, physiological and biochemical responses of plants to nickel stress: A review. African Journal of Agricultural Research 8:1596-1602.
Idrees, M., M. Naeem, T. Aftab, M. Masroor, A. Khan, and Moinuddin. 2013. Salicylic acid restrains nickel toxicity, improves antioxidant defence system and enhances the production of anticancer alkaloids in Catharanthus roseus (L.) Journal of Hazardous Materials 252-253:367-374.

Ishtiaq, S., and S. Mahmood. 2011. Phytotoxicity of nickel and its accumulation in tissues of three Vigna species at their early growth stages. Journal of Applied Botany and Food Quality 84:223-228.

Ismail, M.A., and P.A. Theodor. 2013. Effects of zinc and nickel on antioxidative enzyme activities of hairy roots of Brassica juncea L. Czern (Indian mustard). International Journal of Advanced Biotechnology and Research 3:53-60.

Kachout, S.S., A.B. Mansoura, J.C. Leclerc, R. Mechergui, M.N. Rejeb, and Z. Oueghi. 2009. Effects of heavy metals on antioxidant activities of Atriplex hortensis and A. rosea. Journal of Applied Botany and Food Quality 83:37-43.

Kaveriammal, S., and A. Subramani. 2015. Variation in seed germination and early growth of groundnut (Arachis hypogaea L.) under nickel treatments. International Journal of Environment and Bioenergy 10:47-53.

Kazemi, N., R.A. Khavari-Nejad, H. Fahimi, S. Saadatmand, and T. Nejad-Sattari. 2010. Effect of exogenous salicylic acid and nitric oxide on lipid peroxidation and antioxidant enzyme activities in leaves of Brassica napus L. under nickel stress. Scientia Horticulturae 126:402.407.

Kovacik, J., B. Klejdus, J. Kadukova, and M. Backor. 2009. Physiology of Matricaria chamomilla exposed to nickel excess. Ecotoxicology and Environmental Safety 72:603-609.

Kumar, H., D. Sharma, and V. Kumar. 2012. Nickel-induced oxidative stress and role of antioxidant defense in Barley roots and leaves. International Journal of Environmental Biology 2:121-128.

Lu, M.Y., X.R. Li, M.Z. He, Z.N. Wang, and H.J. Tan. 2010. Nickel effects on growth and antioxidative enzymes activities in desert plant Zygophyllum xanthoxylon (Bunge). Sciences in Cold and Arid Regions 2:0436-0444.

Mahar, A., P. Wang, R. Li, and Z. Zhang. 2015. Immobilization of lead and cadmium in contaminated soil using amendments: A review. Pedosphere 25:555-568.

Maheshwari, R., and R.S. Dubey. 2009. Nickel-induced oxidative stress and the role of antioxidant defence in rice seedlings. Plant Growth Regulation 59:37-49.

Mhamdi, A., G. Queval, S. Chaouch, S. Vanderauwera, F. Van Breusegem, and G. Noctor. 2010. Catalase function in plants: a focus on Arabidopsis mutants as stress-mimic models. Journal of Experimental Botany 15:4197-4220.

Mishra, S., D. Panjwani, B. Mishra, and P.N. Sharma. 2010. Effect of excess nickel on induction of oxidative stress in Zea mays L. plants grown in solution culture. International Journal of Toxicological and Pharmacological Research 2:10-15.

Nadgorska-Socha, A., A. Kafel, M. Kandziora-Ciupa, J. Gospodarek, and A. Zawisza-Raszka. 2013. Accumulation of heavy metals and antioxidant responses in Vicia faba plants grown on monometallic contaminated soil. Environmental Science and Pollution Research International 20:1124-1134.

Nair, R.M., R.Y. Yang, W.J. Easdown, D. Thavarajah, P. Thavarajah, J.A. Hughes, and J.D.H. Keatinge. 2013. Biofortification of mungbean (Vigna radiata) as a whole food to enhance human health. Journal of the Science of Food and Agriculture 93:1805-1813.

Panda, S.K., and M.H. Khan. 2003. Antioxidant efficiency in Oryza sativa leaves under heavy metal toxicity. Journal of Plant Biology 30:23-29. 
Pandey, N., and C.P. Sharma. 2002. Effect of heavy metals $\mathrm{Co}^{2+}$, $\mathrm{Ni}^{2+}$ and $\mathrm{Cd}^{2+}$ on growth and metabolism of cabbage. Plant Science 163:753-758.

Pandey, N., G.C. Pathak, D.K. Pandey, and R.L. Pandey. 2009. Heavy metals, $\mathrm{Co}, \mathrm{Ni}, \mathrm{Cu}, \mathrm{Zn}$ and $\mathrm{Cd}$, produce oxidative damage and evoke differential antioxidant responses in spinach. Brazilian Journal of Plant Physiology 21:103-111.

PARC. 2012. National Coordinated Pulses Programme. Pakistan Agriculture Research Council (PARC), Islamabad, Pakistan. Available at http://www.parc.gov.pk/index.php/en/csi/137narc/crop-sciences-institue/712-national-coordinated-pulsesprogramme (accessed January 2016).

Singh, G., R.K. Agnihotri, D.K. Singh, and R. Sharma. 2013. Effect of $\mathrm{Pb}$ and $\mathrm{Ni}$ on root development and biomass production of black gram (Vigna mungo L.): overcoming through exogenous nitrogen application. International Journal of Agriculture and Crop Sciences 5:1410-1417.

Snedecor, G.W., and W.G. Cochran. 1989. Statistical methods. $8^{\text {th }}$ ed. 503 p. Iowa State University Press, Ames, Iowa, USA.

Sreekanth, T.V.M., P.C. Nagajyothi, K.D. Lee, and T.N.V.K.V. Prasad. 2013. Occurrence, physiological responses and toxicity of nickel in plants. International Journal of Environmental Science and Technology 10:1129-1140.
Suneja, Y., S. Kaur, A.K. Gupta, and N. Kau. 2011. Levels of nutritional constituents and antinutritional factors in black gram (Vigna mungo L. Hepper). Food Research International 44:621-628.

Tewari, A., R. Singh, N.K. Singh, and U.N. Rai. 2008. Amelioration of municipal sludge by Pistia stratiotes L.: Role of antioxidant enzymes in detoxification of metals. Bioresource Technology 99:8715-8721.

Tian, H.Z., L. Lu, K. Cheng, J.M. Hao, D. Zhao, Y. Wang, et al. 2012. Anthropogenic atmospheric nickel emissions and its distribution characteristics in China. Science of the Total Environment 1417-418:148-157.

Yusuf, M., Q. Fariduddin, S. Hayat, and A. Ahmad. 2011. Nickel: An overview of uptake, essentiality and toxicity in plants. Bulletin of Environmental Contamination and Toxicology 86:1-17.

Yusuf, M., Q. Fariduddin, and A. Ahmad. 2012.24-Epibrassinolide modulates growth, nodulation, antioxidant system, and osmolyte in tolerant and sensitive varieties of Vigna radiata under different levels of nickel: A shotgun approach. Plant Physiology 57:143-153. 